\title{
Potemkin and the Panopticon: Samuel Bentham and the Architecture of Absolutism in Eighteenth Century Russia SIMON WERRETT *
}

\section{Introduction}

A building circular... The prisoners in their cells, occupying the circumference-The officers in the centre. By blinds and other contrivances, the Inspectors concealed... from the observation of the prisoners: hence the sentiment of a sort of omnipresence-The whole circuit reviewable with little, or... without any, change of place. One station in the inspection part affording the most perfect view of every cell. ${ }^{1}$

Jeremy Bentham's Panopticon has occasioned much discussion over the past two decades. What Baumgardt could dismiss as 'not of basic ethical interest' for studies of Bentham in 1952, has become a 'central focus' in the 1980s and 90s. ${ }^{2}$ In Bentham's Prison (1993), Janet Semple has traced the progress of the Panopticon within the political context of early nineteenth century England, whilst Ignatieff (1978), Evans (1982), Foucault (1975), Melossi and Pavarini (1981) and many others have considered the place of Bentham's establishment in British penal history. Much of this discussion has centred on the extent to which Bentham's program for a rational, utilitarian society was motivated by a concern for humanitarian reform or more sinister, disciplinary interests. Janet Semple, for example, has reacted strongly to Foucault's notorious view that the Panopticon constituted a 'diabolical piece of machinery' for social control in the nineteenth century. ${ }^{3}$ Semple suggests that Foucault's 'claustrophobic distrust of the world' has led him to depreciate the

\footnotetext{
${ }^{1}$ Jeremy Bentham, Proposal for a New and Less Expensive mode of Employing and Reforming Convicts, London, 1798, quoted in R. Evans, The Fabrication of Virtue: English Prison Architecture, Cambridge, 1982, p. 195.

${ }^{2}$ D. Baumgardt, Bentham and the Ethics of Today. Princeton, 1952, p. 364.

${ }^{3}$ M. Foucault, Power/Knowledge. Selected Interviews and Other Writings, New York, 1980, p. 158.
} 
sincerity of Bentham's intentions. ${ }^{4}$ She prefers to see the Panopticon as the product of 'a realistic, kindly man looking for ways to ameliorate the lot of the poor'. 5

Underlying this debate, however, almost all commentators agree that the Panopticon constituted or helped to constitute a new form of power in the late eighteenth century, although disagreement again arises in relation to the ethical nature of this power. Both Ignatieff and Foucault contrast the ancien and modern regimes of Europe through forms of power specific to each. Ignatieff differentiates between an old paternalist regime, characterized by a weak state and reliance on physical terror to maintain order, and a new regime consisting of a strong state, controlling society through discipline of the mind rather than the body. The Panopticon, for Ignatieff, is emblematic of the new order as 'the most haunting symbol of the disciplinary enthusiasms of the age' ${ }^{6}$ Likewise, Foucault views the Panopticon as a 'cage, cruelle et savante', an idealized microcosm of nineteenth century society, where discipline has become institutionalized in schools, hospitals, prisons and asylums, operating through the internalized subjection imbued through surveillance. He posits a radical discontinuity between this 'disciplinary society' and the ancien regime, where power is articulated through theatrical displays of sovereign authority, exemplified in the spectacular politics of the public execution. According to Foucault, these two forms of 'sovereign' and 'disciplinary' power are 'absolutely incompatible'.

Semple prefers to identify the Panopticon with the growth of representative democracy, or at least its Benthamite variety. She argues that as a penitentiary, the Panopticon represented the inverse of Bentham's plans for a new and positive 'democratic' system of power, in which government would be made public and accountable to ensure the greatest happiness of the greatest number. By means of the inspection principle, applied through public tribunals, 'panoptic' government offices and freedom of the press, power would at all times remain under the scrutiny of the populace.

It may seem that little remains to be said concerning Bentham's Panopticon. But there are problems with these contemporary views. Primarily, the Panopticon has

\footnotetext{
${ }^{4}$ J. Semple (1993), Bentham's Prison: A Study of the Panopticon Penitentiary, Oxford, 1993, p. 322.

${ }^{5}$ Ibid.,_pp. 314-15.

${ }^{6}$ M. Ignatieff, A Just Measure of Pain: the Penitentiary in the Industrial Revolution, New York, 1978, p. 109.

${ }^{7}$ Foucault, Power/Knowledge, p. 104.
} 
been studied only as Jeremy Bentham's penitentiary, and hence as a project which failed: whilst Bentham spent some twenty years attempting to build the establishment in London, he was finally forced to abandon the scheme in 1809 under pressure from the British government. Consequently, commentators tend to view the Panopticon more as a philosophical exercise or idealized invention of Jeremy Bentham than as a practicable project with its own development and history. By ignoring this history, there has also been a tendency to equate the Panopticon with Jeremy Bentham's mature utilitarian philosophy and the radical anti-monarchy, democratic standpoint he took up towards the end of his life. Gertrude Himmelfarb pointed this out as long ago as 1965, suggesting that in its earlier forms, 'the Panopticon seems to bear out the judgment of non-Radicals more than that of Radicals' so that 'it may be necessary to re-examine the conventional image of Bentham as the father of reform and of Philosophical Radicalism as the fount of reform'.

Himmelfarb's point is suggestive: by considering the Panopticon in its various historical manifestations, she demonstrated the changing nature of the establishment in relation to Bentham's thought. In this paper I take this approach further and consider the Panopticon in its first incarnation, as it was designed by Samuel Bentham, Jeremy's brother, on an estate in White Russia during the autumn of 1786. I argue that when the Panopticon is examined in relation to the Russian context in which it was designed, its association with the disciplinary mechanisms of social control in the nineteenth century, and its incompatibility with the forms of power exercised by the ancien regimes, must become problematic. As Samuel Bentham's establishment, I suggest, the Panopticon was intimately connected with the system of absolutism in Russia.

\section{Samuel Bentham in Russia.}

The Panopticon was first designed during the autumn of 1786 on the estate of Krichev in the southern Mogilev province of White Russia, partitioned from Poland in 1772. ${ }^{9}$ Jeremy had arrived at the estate earlier that year, and occupied himself writing The

\footnotetext{
${ }^{8}$ G. Himmelfarb, Victorian Minds, New York, 1968, p. 81. For Semple's criticisms of Himmelfarb, see 'Bentham's Haunted House', The Bentham Newsletter, xi (1987), pp. 35-44.

${ }^{9}$ See E.I. Druzhinina, Severnoe Prichernomore, v 1775-1800 ['The Northern Shores of the Black Sea'], Moscow, 1959, pp. 82-84 and E.P. Zakalinskaya, Votchinnye Khoziaistva Mogilevskoi Gubiernii vo
} 
Defense of Usury at a retreat in the village of Zadobrast. Struck by 'the plan of a building, lately contrived by my brother, under the name of the Inspection House or Elaboratory', Jeremy incorporated the idea into his own plans for a penitentiary in answer to a competition being held by the St. James Chronicle to design a new prison for Middlesex. Jeremy sent his plans to his father to be printed for a limited circulation in December 1786, in the form of a series of letters, eventually published as Panopticon; or, The Inspection House in 1791.

The estate belonged to Prince Grigorii Potemkin, the most influential of Catherine II's favorites during the 1780s. It comprised approximately 1000 square miles, with five towns and more than a hundred hamlets. By 1784, Potemkin had built up numerous manufactories there for his own profit: including a glass factory, copperworks, tannery and leatherworks. In the central town of Krichev, a textile mill and ropewalk produced materials for shipbuilding at Kherson.

Samuel Bentham had come to Russia in search of work as a naval engineer in 1780. ${ }^{10}$ After joining the community around the British Factory in St Petersburg, Bentham made a tour and study of the mines and manufactories of the Urals in 178182. Returning to St Petersburg, Bentham entered the service of Potemkin in 1784. He was sent to Krichev to manage the Prince's manufactories and to build vessels for transporting shipbuilding materials down the Dnepr to the port of Kherson on the Black Sea. In return, the Prince gave him a house, servants and a large serf labour force, as well as unlimited funds to improve the estate, and freedom to make experiments and prepare inventions. The Inspection House was amongst numerous innovations he introduced to the estate. However, whilst plans were made to construct the Panopticon at Krichev, the project never materialized. Prince Potemkin sold his

Vtoroi Polovine XVIII Veka [Patrimonial Economics of the Mogilev District in the Second Half of the Eighteenth Century], Mogilev, 1958 pp. 56-71 for the development of Kherson and Krichev.

${ }^{10}$ On Bentham's career, see M.S. Bentham, 'Memoir of the Late Brigadier Sir Samuel Bentham', Papers and Practical Illustrations of Public Works of Recent Construction, London, 1856, and The Life of Brigadier-General Sir Samuel Bentham, KSG, by his Widow, London, 1862; W.L. Sargant, Essays of a Birmingham Manuscfacturer, London, 1869. On Bentham in Russia, see: M.S. Anderson, 'Samuel Bentham in Russia, 1779-1791', The American Slavic and East European Review, xv (1956), pp. $157-$ 172; W. Kirchner, 'Samuel Bentham and Siberia', Slavonic and East European Review, xxxvi (1958), pp. 471-80; K.A. Papmehl, 'The Regimental School Established in Siberia by Samuel Bentham', Canadian Slavonic Papers, viii (1966), pp. 153-68; I.R. Christie, 'Samuel Bentham and the Western Colony at Krichev, 1784-1787', Slavonic and East European Review, xlviii (1970), pp. 232-47, 'Samuel Bentham and Russian Dnieper Flotilla', Slavonic and East European Review, c (1972), pp. 173-97, 'Samuel Bentham's Library in Russia', Slavonic and East European Review, 1xv (1987), pp. 26-37, and The Benthams in Russia, 1780-1791, Oxford, 1993. 
estate in May 1787, and Samuel Bentham was forced to leave to take part in naval engagements with Turkey.

Although many studies note the origins of the Panopticon in Russia, none give more than passing attention to the reasons for which the establishment was designed. In his book-length study of The Benthams in Russia, Ian Christie is typically brief:

Samuel's preoccupation with the general problem of the supervision of unskilled labour gave birth during 1786 to the famous scheme of "central observation" [...] Samuel conceived that the training and supervision of large numbers of unskilled Russian workmen [...] might be best carried out in an "Inspection House". 11

Similarly, Janet Semple writes:

It was in an attempt to employ ignorant ...peasants effectively in manufacturing that Samuel devised a circular inspection house that would enable each workman to be supervised from a central observation post. $^{12}$

These brief explanations miss a crucial distinction in the immediate problems leading to the design of the Krichev Panopticon. Bentham faced both problems of skill and problems of discipline with his workforce. As Semple and Christie maintain, problems of skill faced Bentham from the beginning of his stay at Krichev, as he attempted to train peasants in shipbuilding crafts. But such problems were far from unique in Russia. Numerous Englishmen complained of the lack of skilled workers for their projects. The engineer John Phillips, recruited to build a canal uniting the

\footnotetext{
${ }^{11}$ Christie, Benthams in Russia, p. 177.

${ }^{12}$ Semple, Bentham's Prison, pp. 99-100. Many of these studies give contradictory information regarding Samuel's role in this design. Evans and Ignatieff mistakenly note that 'Samuel was building a sizeable manufactory around a core of director's rooms from which the whole establishment could be easily overlooked'. Markus even suggests that Jeremy Bentham devised the Panopticon in order to solve Samuel's needs for supervision. See Evans, Fabrication of Virtue, p. 196; Ignatieff, Just Measure of Pain, p .196; and T. Markus, Buildings and Power: Freedom and Control in the Origins of Modern Building Types, London, 1993, p. 123.
} 
Caspian to the Baltic Sea, complained that after nineteen months of work no skilled artificers could be found, so that 'he returned to Petersburg, without doing anything but cutting down a few thousand timber trees' ${ }^{13}$

Bentham's initial solution to this skill shortage was to import expertise from England. From June 1784, with the financial support of Potemkin, Samuel began recruiting English masters from London. Over the winter of 1785, he built up a core of approximately twenty skilled workmen. In addition to a sailmaker, joiner and bricklayers, the group included one James Love, recruited as a model builder, Anthony Young, a millwright, John Bell, the ship's master, and Robert Beatie, who took charge of Potemkin's hemp factory. Their task was to supervise the various activities on the estate and to train the peasant workers in shipbuilding and manufacturing.

At no time, however, did the peasants offer Bentham any particular problems of discipline. On the contrary, in one case, it was they who trained Bentham in such matters. In September 1784, Potemkin had given Bentham charge of a battalion of serf infantry. Unacquainted with army discipline, Bentham grudgingly accepted instruction from the battalion sergeants on keeping the men in order. ${ }^{14}$ In contrast, by the summer of 1786, the English supervisors became increasingly difficult to control. One of Bentham's recruits, Dr. John Debraw, formerly apothecary to Addenbroke's Hospital in Cambridge, was given charge of the English workmen. In September 1786, Debraw submitted a report to Bentham, damning the lack of discipline among the Englishmen. His 'Journal of Transactions' listed 'laziness, thievery, quarreling, drinking' as amongst their attributes, likening them to 'a Newcastle election mob' or 'hirelings from that rabble town'. ${ }^{15}$ Bentham lamented the discord: 'I have so few assistants on whom I can put the least dependence [...] Morning after morning I am taken up chiefly with disputes amongst my Officers'. ${ }^{16}$ One supervisor, George Benson, who had been taken on as a chemical projector, caused particular problems. After 'he had his quarrels with most of the English and had well nigh drove a very

\footnotetext{
${ }^{13}$ J. Phillips, A General History of Inland Navigation, Foreign and Domestic, London, 1805, pp. 36-7.

${ }^{14}$ M.S. Bentham, Life, pp. 78-9.

${ }^{15}$ The Works of Jeremy Bentham, ed. J. Bowring, 11 vols., Edinburgh, 1843, x. p. 161. Hereafter 'Bowring'.

${ }^{16}$ British Library Add. Ms. 33540 fo. 178-9. Jeremy Bentham also noted ' $\mathrm{t}$ ] hat there is a lack of discipline and order among the workmen is but too true'. The Correspondence of Jeremy Bentham, ed. I.R. Christie, Oxford, 1971 (The Collected Works of Jeremy Bentham), iii. p. 498. Hereafter Correspondence $(\mathrm{CW})$.
} 
able work man out of the service', ${ }^{17}$ Benson threatened to write to Potemkin, Catherine and William Pitt to complain of the Benthams, who had reproached him over his conduct. It was in the course of settling the matter that Jeremy wrote the Panopticon Letters. In his correspondence he discussed the Panopticon alongside accounts of the 'two legged tormentor' Benson. ${ }^{18}$

It seems more likely then, that the specific problem of poor discipline among these English supervisors formed the immediate reason for designing the Krichev Panopticon. The establishment did provide a means for supervising the training of unskilled peasants, but only to the extent that the trainer was able to see when he was required, before going to the worker in need of assistance:

With regard to instruction, in cases where it cannot... be given without the instructor's being close to the work, or without setting his hand to it by way of example before the learner's face, the instructor must indeed, here as elsewhere, shift his station as often as there is occasion to visit different workmen. ${ }^{19}$

The Panopticon offered no significant development on the usual method of a trainer overseeing his workforce. So Bentham's invention was not so much an attempt to employ 'ignorant Russian peasants effectively', but rather a solution to the immediate and very real problem of 'who will guard the guards?'

Paying more attention to the specific environment within which the Panopticon originated can add much more to our understanding of Bentham's institution. But that environment may be broadened out much further than the immediate difficulties facing Bentham with his supervisors, by making a closer examination of the context for his work. Bentham's activities at Krichev were closely connected with the personalities, institutions and characteristics of the Russian culture in which they took place. I now consider this context in more detail, beginning with Bentham's patron, Prince Potemkin, whose courtly machinations turn out to be crucial for understanding the Panopticon.

\footnotetext{
${ }^{17}$ Ibid., p. 504.

${ }^{18}$ Ibid., p. 503.
} 
For most of Catherine the Great's rule, two opposing parties, one surrounding the Orlov brothers and another led by Nikita Panin, vied for authority in the Russian Government. ${ }^{20}$ By 1780, the Panin party had largely superseded the Orlovs in influence. Potemkin also vied to consolidate his power. In 1776, he had been charged with developing southern territories recently captured from Poland and Turkey. His apportioning of vast funds for these developments was met with indignation by members of Panin's camp, who recognized that Potemkin's activities were being directed towards impressing Catherine, to their own detriment. Consequently, whilst Potemkin laboured in the south, numerous intrigues developed against him in St. Petersburg. So when he returned to the capital in 1784, Potemkin suggested to Catherine a tour of the southern provinces and the Crimea, to survey his work there and to demonstrate her sovereignty of the new territories to both their inhabitants and the Turks. By removing Catherine from the capital, Potemkin could cut off his enemies' influence, and simultaneously dazzle the Empress with 'the grandest spectacle of her reign', ${ }^{21}$ a 6000 mile round trip passing through Kiev to the port of Kherson and on to the Crimea.

With Catherine's consent, Potemkin began directing preparations for the tour throughout the southern territories. His intention was to create an idealization of what Russia might become under the enlightened Empress. As Stephen Baehr has shown, throughout her reign Catherine was portrayed as a 'planter' or 'gardener' in symbolic literature and court ceremony, allying the Tzarina with the image of God as the creator of Eden. Her policy of imperial expansion, colonization and 'civilization' was likened to the establishment of a paradisical new Eden in Russia. ${ }^{22}$ Potemkin attempted to embody this paradise myth in his development of the south: the tour would demonstrate to Catherine the 'Russian Eden' which her policies were creating. This was not, however, the Eden of Genesis, but an 'Enlightenment garden' where 'people are encouraged (rather than forbidden) to partake of the tree of knowledge

\footnotetext{
${ }^{19}$ Bowring, iv. p. 41.

${ }^{20}$ See D.A. Ransel, The Politics of Catherinian Russia: The Panin Party, London, 1975.

${ }^{21}$ J.T. Alexander, Catherine the Great: Life and Legend, Oxford, 1989, p. 256. For description of the tour, see V. Cronin, Catherine, Empress of all the Russias, London, 1978, chapter 21; Henri Troyat, Catherine the Great, Oxford, 1978; on Potemkin's preparations, see A.G. Brikner, Potemkin Sochinenie, St Petersburg, 1891, pp. 80-103; A.M. Panchenko, 'Potemkinskie Derevni Kulturnii Mif ['Potemkin Villages as a Cultural Myth'], XVIII Veka, xiv (1983), pp. 93-105.

${ }^{22}$ S.L. Baehr, The Paradise Myth in Eighteenth Century Russia, Stanford, 1991.
} 
and rewarded with a paradise of perpetual progress'. ${ }^{23}$ New Russia would reflect the ancient metaphor of the 'cultivation' of knowledge, it would be the 'garden of the sciences' [sad nauk] as Fialkovskii described the nation in $1786 .{ }^{24}$

Potemkin's garden soon mixed imperial splendour and economic advancement. In the wake of the liberation of the nobility from state service, Potemkin geared his southern development to the production of profit, the real fruit of the new Russian Eden. As Bentham noted, Potemkin planned 'a Botanical Garden in the Crimea in which if possible all the vegetable productions of the world are to be collected' and a model dairy for the production of 'as many different kinds of cheese as possible'. To enhance this 'happy garden state' Potemkin also planned to 'introduce the use of Beer in his governments and permit the sale of it without any excise'. ${ }^{25}$ In Sevastopol, he recruited Admiral Thomas Mackenzie to construct a new port, dairy, vineyards and botanical gardens. ${ }^{26}$ To demonstrate the fruits of this Enlightened gardening, Potemkin planted his botanical and agricultural projects amidst paradisical surroundings. Palaces were constructed at Sevastopol and Bakhchisaray and English gardens were arranged at Simferapol. Idealised towns were also founded, based on the rational planning of the capital. In April 1787, Alyeshin was completed on the left bank of the Dnepr opposite the new port of Kherson, and Ekaterinoslav, meaning 'Catherine's Glory' was founded in late 1786. Then, between January and July 1787, Catherine undertook her survey of all these enlightened splendours.

From the beginning, Samuel Bentham's activities at Krichev were connected with the Crimean tour. Besides managing the factories there, he was also commissioned to construct a royal barge on which Catherine would travel down the Dnepr to the Crimea, and further vessels for her entourage. In addition, in June 1784, Potemkin requested him to recruit personnel for the Botanical Garden and model dairy under construction for the tour. Christie supposes these activities were supplementary to Bentham's shipbuilding and manufacturing work at Krichev, undertaken for the general reason that 'one of Potemkin's most cherished desires was the establishment of a Black Sea fleet capable of sweeping the Turks off the

\footnotetext{
${ }^{23}$ Ibid., p. 79.

${ }^{24}$ Ibid., p. 79.

${ }^{25}$ Correspondence $(C W)$ p. 269.

${ }^{26}$ Cronin, Catherine, p. 248.
} 
Euxine' ${ }^{27}$ However, it seems more likely that the reason for Bentham's appointment was to improve the estate in preparation for Catherine's tour. Krichev formed part of the Empress's itinerary: Catherine would visit at the end of May 1787.

Furthermore, whilst there is no doubt that Bentham's work was largely directed at improving the fleet, Christie's account fails to explain why he also took charge of projects unconnected with shipbuilding. In June 1784, Samuel sent Jeremy a request for assistants to improve the brewery and distillery at Krichev and made numerous experiments to this end himself. ${ }^{28} \mathrm{He}$ did much to develop gardening and agriculture at nearby Zadobrast, introducing an English strain of potatoes to the estate, planning a model hoggery, and experimenting with the cultivation of new grasses. He collected literature including Miller's Gardeners Dictionary and Young's Annals of Agriculture, and employed John Aiton, nephew of George III's gardener at Kew, to make experiments in cultivation. Christie admits 'his motives for this are not wholly clear'. ${ }^{29}$ But such activities would make sense if the estate was intended for Catherine's inspection. Bentham's horticultural and manufacturing experiments would contribute to the formation of the 'Enlightenment Garden' which Potemkin was creating for the Empress. With manufactories 'more compleat than any in England, ${ }^{30}$ and brought 'to a degree of perfection', $1^{31}$ Bentham would present the Imperial tour with an idealised Russian production estate, part of Potemkin's idealised Russian Eden.

\section{Theatricality in Russian Culture}

Potemkin's demonstration of an idealised Russian nation to the Empress was characteristic of eighteenth century Russian culture, in its use of theatrical display and spectacle. Yuri Lotman has observed that in the course of the Russian nobility's enthusiasm for theatre, 'the dividing line between art and the everyday behaviour of the audience was expunged. The theater invaded life'. ${ }^{32}$ Richard Sennett has argued that this intertwining of everyday conduct with the world of theatre formed a common

\footnotetext{
${ }^{27}$ Christie, Benthams in Russia, p. 234.

${ }^{28}$ Correspondence $(C W)$ pp. 269-72.

${ }^{29}$ Christie, Benthams in Russia, p. 173.

${ }^{30}$ Bentham quoted in ibid., p. 170.

${ }^{31}$ M.S. Bentham, Life, p. 19.

${ }^{32}$ I.M. Lotman and B.A. Uspenskii, The Semiotics of Russian Culture, Michigan, 1984, p. 145.
} 
characteristic in eighteenth century European society. ${ }^{33}$ However, Lotman argues that whilst as in Europe the division between theatre and reality was deleted for the Russian nobility, it was replaced by a unique distinction between what was Russian and what was foreign. ${ }^{34}$ After the introduction of western manners and styles into Russia by Peter the Great, ' $[\mathrm{t}]$ he alien and the foreign became the norm'. ${ }^{35}$ Consequently, 'to conduct oneself correctly was behave like a foreigner, that is act in an artificial way according the norms of alien lifestyle' ${ }^{36}$

Lotman observes that this role-playing served a political function. Theatricality could enhance the noble's reputation with the monarch, to the extent that theatricality identified him with the west: 'theatricality was an attribute of power [...] noblemen [...] displayed their standing by imitating Europeans while remaining Russians'. ${ }^{37}$ In particular, it was the enlightened westerner who provided the role model for the nobility, evinced by an increasingly avid consumption of French, German and Italian books on enlightened culture and conduct. ${ }^{38}$

The nobility soon paraded their knowledge of the West in the fashionable quarters of St. Petersburg, the Frenchified fop and amateur philosopher appearing amidst the social mileau by the 1760s. But as Priscilla Roosevelt has argued, the key site for these western theatricals was the noble estate. ${ }^{39}$ Since political and social reputation was dependent on the successful fashioning of a 'foreign' identity, the estate provided the only space for such fashioning entirely under the nobility's control. Consequently, estates were frequently used for extravagent spectacles to impress the sovereign. Many became completely transformed into idealised or imaginary foreign landscapes. When Potemkin celebrated the capture of Ismail in 1791, his estate was transformed into a southern landscape, with Caucasian mountain ranges, re-enacted

\footnotetext{
${ }^{33}$ R. Sennett, The Fall of Public Man, New York, 1977.

${ }^{34}$ Lotman and Uspenskii, Semiotics, chapter 10.

${ }^{35}$ Ibid., pp. 232-33.

${ }^{36}$ Ibid.

${ }^{37}$ R.S. Wortman, Scenarios of Power: Myth and Ceremony in Russian Monarchy From Peter the Great to the Death of Nicholas I, Princeton, 1995, p. 86. See also Lotman and Uspenskii, Semiotics, p. 233.

${ }^{38}$ These books, yet to be studied, were crucial in the transfer of Western culture to Russia. The Florinova Ekonomia, for example, translated from German by Sergei Volchkov in 1738, explained new western techniques of farming, manners, manufactures, medicine, hore riding, building, cookery and domestic economy to its Russian audience, going through five editions by 1794.

${ }^{39}$ P.R. Roosevelt, 'Emerald Throne and Living Statues: Theater and Theatricality on the Russian Estate', The Russian Review, c (1991), pp. 1-23.
} 
sea battles and guests dressed as Turks, Indians and Italians, who walked through gardens transformed into arcadian groves and elysian fields. ${ }^{40}$

Potemkin's imperial tour belonged precisely to this tradition of theatricality in Russian culture. Seeking to maintain prestige and influence with the Empress, Potemkin transformed the lands he had captured from the Poles and Turks into a vast stage for his utopian visions. This stage he carved up into a series of estates, to be filled with the scenery of an idealised new Russia, an 'Eden' of enlightened manufactures, agriculture, science and splendour. Potemkin then took Catherine on a tour through these estates, in a series of dramas where the Empress and her noble entourage might act out their fantastical roles as enlightened foreigners. The tour was a grand example of theatre invading life, a theme with which Potemkin consciously played throughout the tour. It was theatricality that informed his famous 'Potemkin villages', rows of wooden building frontage constructed for the tour, set up to give the impression that one was passing through a 'real' estate. The villages were stage scenery on a grand scale. During the tour, foreign guests in the royal entourage ridiculed the villages as 'sets' constructed to make the Empress believe Potemkin had built more than he claimed in the south. But they failed to appreciate that the villages, like the transcient and imaginary landscapes of the noble estate, were part of the natural theatricality of Russian life. Potemkin's stage sets impressed Catherine just as much as real estates.

The estate of Krichev shared in this Russian culture of theatricality. As part of the Crimean tour, Bentham and Potemkin's efforts transformed the estate into a landscape of enlightened prosperity, an idealisation of Russias potential as a 'garden of the sciences', to be presented to the Empress and her noble entourage. It was amidst this theatre of horticulture, model factories, palaces and gardens that the Panopticon was to be built. Besides offering a solution to Bentham's immediate problems with his undisciplined supervisors, the Panopticon formed part of Potemkin's theatrical display for the Russian court.

In fact, Jeremy Bentham explicitly stated that theatricality was a central component of the Panopticon. In its later prison form devised by the Benthams and the architect William Reveley in 1791, an inspection gallery for visitors was situated above the Inspector's office. Since the prisoners would be made to wear masks before

${ }^{40}$ Ibid., p. 21. 
the visitors, Bentham described his institution as 'a Masquerade', a theatre 'serious, affecting and instructive'. He even praised the Inquisition for its 'stage effect' and suggested 'in a well composed committee of penal law, I know not a more essential personage than the manager of a theatre'. ${ }^{41}$ In the Panopticon developed at Krichev, however, this theatricality was preserved not in an inspection gallery, but in the Inspector's lodge. Unlike later designs for the lodge, consisting of simple offices for the Inspector, the Krichev Panopticon was to contain 'a complete and constant habitation for the principal inspector... and his family'. ${ }^{42}$ In effect, this was a translation of Bentham's Krichev house to the centre of the Panopticon. Those present in such a house would be provided with a 'great and constant fund of entertainment' as they stared out of the windows onto the cells around them: ' $[\mathrm{t}]$ he scene, though [...] confined, would be a very various, and therefore, perhaps, not altogether an unamusing one'. ${ }^{43}$ At Krichev, such a scene would consist of Bentham's serfs, employed on a series of wood-working machines he planned to install in the establishment.

Unlikely an amusing scene for Samuel Bentham, the layout of the Panopticon planned for Krichev would have been familiar to any noble visitor. In effect, the Panopticon subsumed the spatial structure of the Russian estate into a single building: the family house, the noble at the centre, his peasant workforce surrounding him. These peasants would not be employed in their traditional agricultural or craft work, however, but on Bentham's wood-working machines- some of the most advanced machinery in Russia at the time. ${ }^{44}$ This was precisely the kind of enlightened panorama which Potemkin sought to demonstrate on the tour. Like Krichev itself, or the grand stage of the southern territories, the Panopticon presented an idealisation of what the Russian estate might become under the watchful eye of the enlightened Empress Catherine and her nobility: a western, enlightened production utopia, constructed amidst the horticultural splendour of a restored Eden. The innovation of the Inspector's lodge made room for this Imperial fantasy. At once a solution to Bentham's problem of disciplining his English supervisors, the lodge also provided a

\footnotetext{
${ }^{41}$ Bowring, iv. pp. 79-80.

${ }^{42}$ Ibid., p. 45.

${ }^{43}$ Ibid., p. 45.

${ }^{44}$ Bentham's block-making machinery, devised in concert with Marc Brunel, made his name in England a few years later. See C. Cooper, 'The Portsmouth System of Manufacture', Technology and Culture, ii (1984), pp. 182-226.
} 
space in which the Russian noble, or even the Empress, playing the inspector, might act out the role of the enlightened foreigner. The architecture of the inspector's lodge embodied exactly the self-appointed role of the Russian courtiers on the tour, passing in and out of spaces where they might play at being foreigners in an enlightened utopia. The Panopticon, like Potemkin's villages or the stage sets of the nobility, played on the theatricality of the Russian estate.

\section{Russian Orthodoxy and the place of power.}

If the Panopticon was intended to demonstrate the ideal of an enlightened estate to the noble placed at its centre, what was the significance of discipline and surveillance in this, which were, after all, the primary functions of the establishment? For Bentham, surveillance offered a means to control the troublesome English workers on his estate. But for the Russian noble, the Panopticon offered a means to control the peasantry. Why this should be significant becomes clear if consideration is given to the traditional way in which the peasantry were controlled in Russia, through the Orthodox church.

In the eighteenth century, the Russian peasantry learnt their place in the world through their relationship to God. The place where this process was played out was the Orthodox church. It was here that social identity was defined through a spatial structure, inherited from the Byzantine model, in which visibility played the central role. In this respect, there are close parallels between the system of power in operation in the Panopticon and that in the Orthodox church. When the Krichev Panopticon is considered within the context of the impending tour, these parallels are crucial.

The most important feature of the Orthodox church is that it constitutes for the Orthodox an extension of the Incarnation, making manifest the body of Christ on Earth: '[t]he Church is one and the same with the Lord- His Body, of His Flesh and of His Bones'. ${ }^{45}$ This is not a metaphorical or symbolic relation. For the Orthodox, the church is the body of Christ, constituting 'a continuation and extension of His power', a physical space in which Christ's presence may be experienced and his mysteries contemplated. ${ }^{46}$ For this reason, the architecture of the Russian church serves to

\footnotetext{
${ }^{45}$ Patriarch John of Kronstadt quoted in T. Ware, The Orthodox Church, London, 1963, p. 243.

${ }^{46}$ Andoustros (1907) p.262.
} 
enhance this experience. Its structure and imagery act to demonstrate Christ's omnipotence and omniscience to those present.

The majority of Orthodox churches are based on the pattern formulated in the ninth century, of a cross within a square, surmounted by a dome. ${ }^{47}$ The dome is a central feature. As the church constitutes an extension of the Incarnation, so the dome symbolizes 'the earthly heaven in which the heavenly God dwells and moves'. ${ }^{48}$ Consequently, the dome is often covered by the image of Christ Pantokrator, the 'Ruler of All' . This iconographical scheme, with Christ's eyes emphasized and His hand pointing to the Book of Judgment, serves to recall the omniscient character of God and the means by which Divine Law was made known to man. Thus, the Byzantine Patriarch Photius described the image as 'Christ... looking down over the world, and considering its order and... government' ${ }^{49}$

Christian churches in the west, by contrast, are characterised by their tall towers and spires. Sennett argues that this height translated into architecture the Augustinian notion of finding God through vision, of 'seeking the light', so that, like Augustine's City of God, the Judeo-Christian church constituted '[a] shadow [...] of the eternal city [...] cast on earth, a prophetic representation of something to come rather than a real presentation in time. ${ }^{50}$ The height of the tower defines a distance and dislocation from God, to be overcome in this world if one seeks salvation in the next. As such, the western church differs radically from the Orthodox. The architecture of the western church symbolizes the possibility of experiencing God, whilst that of the Orthodox embodies the actuality of this experience, as it defines the presence of God on earth.

But whilst the presence and power of God must be experienced in the Orthodox church, the operations of this power must remain unknown: 'we know... that the word of God is true, active and omnipotent, but in its manner of operation unsearchable'. ${ }^{51}$ The Orthodox sacraments are referred to as the 'divine mysteries' of which the Eucharist is the most important. In contrast to the Western church, the Orthodox refuses to use the notion of Transubstantiation to describe consecration, since this would constitute an explanation of the holy mysteries. Instead, the Orthodox liturgy

\footnotetext{
${ }^{47}$ On Orthodox church architecture, see Brumfield (1995); Buxton (1934); Hamilton (1954).

${ }^{48}$ Germanus, Patriarch of Constantinople, quoted in Ware, Orthodox Church, p. 269.

${ }^{49}$ H. Wybrew, The Orthodox Liturgy: The Development of the Eucharistic Liturgy in the Byzantine Rite, London, 1989, p. 107.

${ }^{50}$ Augustine quoted in Sennett, Public Man, p. 7.

${ }^{51}$ John of Damascus quoted in Ware, Orthodox Church p. 292.
} 
uses the term metabollo, meaning 'change'. Again, this doctrine of the mysteries is reflected in the architecture of the church. A large circular nave occupies the centre of the church, entered through the narthex or inner porch. The laity, standing in the nave, face a sanctuary, in which the clergy perform the rituals of the Eucharist. In contrast to the Western church, however, the Orthodox contains a screen separating the nave and sanctuary called the templon or iconostasis. ${ }^{52}$ During the Liturgy, the clergy move in and out of the sanctuary through 'holy doors' in the iconostasis. When the rites of metabollo are performed, they remain inside the sanctuary, with the doors closed and a veil drawn across them, such that the laity are cut off both from hearing the central prayers and seeing the central actions of the Liturgy. ${ }^{53}$ Instead, the laity stand contemplating the screen of icons and the church surrounding them. Amongst the icons, they might see 'Christ the Angry Eye', which, like the Pantokrator in the dome, provides another representation of God's omniscience and judgment. In this way, the iconostasis serves to make the holy mysteries invisible and inaudible from the laity. So the doctrine of mystery is articulated in the Orthodox church through this asymmetry of visibility. The spatial structure of the church acts as the physical extension and demonstration of God's omniscience and omnipotence, at the same time hiding the source of His power through the intersection of the iconostasis.

This Orthodox architecture acted as a central constituent in the structuring of the social hierarchy in Russia. The asymmetry of visibility created by the iconstasis separated those who were permitted to see the power of God at work, the ordinated clergy, and those who were not, the peasantry. This served to define the role of participants in orthodox ritual. The clergy were active, controlling their own visibility, and that of the sacred actions which only they were permitted to perform. In contrast, the peasants in the nave were passive, their only obligation being to "pray with their eyes'. Contemplating the icons on the screen and in the dome, they understood that God was judging and watching over them. In this way, the peasant learnt his or her place in the world: a passive role of obedience to God and to those privileged with knowledge of divine power, a role which accorded with the peasant's lowly position in the social hierarchy.

\footnotetext{
${ }^{52}$ Wybrew, Orthodox Liturgy, p. 147.

${ }^{53}$ Ibid., p. 148.
} 
Let us now consider the Panopticon as it relates to the Orthodox church. Jeremy Bentham was quite explicit that the power of surveillance in the Panopticon could be likened to the action of an omniscient God. Bentham referred to 'the apparent omnipresence of the inspector [...] combined with the extreme facility of his real presence' as the fundamental principle of his prison. ${ }^{54}$ The frontispiece of the first edition of the Letters was to have been a quotation from Psalm 139:

Though art about my path, and about my bed: and spiest out all my ways. If I say, peradventure the darkness shall cover me, then shall my night be turned into day. Even there also shall thy hand lead me; and thy right hand shall hold me. ${ }^{55}$

This does not suggest any direct relation between the orthodox church and the Panopticon, yet what was central to both the Panopticon and the Church was that this apparent omnipresence was expressed through architecture. In both structures, an asymmetry of power is articulated through an asymmetry of visibility, the notion of 'seeing without being seen'. In the Orthodox church, divine power, the act of metabollo is hidden from the sight of the laity. At the same time, the image of Christ, in the icons and Pantokrator, confronts them from the iconostasis and dome, to generate the impression that whilst they cannot know the source of divine power, that same power is watching and judging over them. Their obedience is to God, and to those permitted to see his mystery, the clergy. In the Panopticon, the inspector, located in the central lodge, is hidden from the sight of the prisoners, but at the same time, the prisoners are given the 'intense feeling' of being watched. This 'apparent omniscience' ensures obedience. In effect, the architecture of the Panopticon presented a secularized form of the power mechanisms of the Orthodox church.

It may seem unlikely for Samuel Bentham to devise a 'secularized church' at Krichev. Yet the designs which he prepared with Jeremy in 1786 bear a close resemblance to the church architecture of the time. Compare, for example, the Krichev Panopticon with Starov's design for the Cathedral of the Trinity finished in 1782 . Bentham was certainly well informed about the Orthodox church. During a

\footnotetext{
${ }^{54}$ Bowring, iv. p. 45.

${ }^{55}$ Frontispeice is reprinted in Evans, Fabrication of Virtue, p. 200.
} 
tour of Siberia in 1781 Bentham collected information on the activities of the Raskolniki or Old Believers for the government: precisely a surveillance operation undertaken to undermine the power of a section of the Orthodox community. ${ }^{56}$

If Bentham was presenting a 'secularized church' to his audience, this would not have been extraordinary in the context of Catherinian Russia. In a long process of secularization, church land, property and privileges had been continuously diminished from the time of Peter the Great, culminating in 1764, when Catherine decreed that all church property had to be handed over to the state. ${ }^{57}$ So secularization was at its height in White Russia at the time the Benthams designed the Panopticon there in 1786. As Jeremy noted in the Letters: 'we are dissolving monasteries as you would lumps of sugar. A lump [...] we got the other day at Kieff, enough to feed a brace of regiments' ${ }^{58}$ Whilst large monasteries were being dissolved completely, smaller ones were ordered to convert their property to state uses. The 1770 s and 80 s witnessed a large scale conversion of ecclesiastical buildings into hospitals, prisons, schools and asylums, so by 1786 , secularized churches were becoming commonplace in the Russian landscape. ${ }^{59}$

Russian culture also changed through this process of secularization. As the autocracy consolidated an ideology based on the absolute monarchies of Europe, the Russian court increasingly appropriated the iconography of the Orthodox church to create what Stephen Baehr has called a 'religion of state' ${ }^{60}$ Catherine was portrayed as the 'planter of Eden' for example. The transition was also apparent in noble theatre, which came to incorporate an opposition between the religious and the secular complementary to that between the Russian and the foreign, the old and the new. In the course of time, religious culture became equated with the old and the Russian, and consequently the object of a similar scorn and ridicule. But religion was not rejected outright. As the nobility took increasingly to the role-playing which their taste for the foreign implied, they turned first to the traditional, 'official' rituals of the church,

\footnotetext{
${ }^{56}$ Christie, Benthams in Russia, p. 71.

${ }^{57}$ A. Preobrazhenskii, Russkaya Pravoslavnaya Tserkov, $X-X X v v$ [The Russian Orthodox Church, $10^{\text {th }}$ to $12^{\text {th }}$ Centuries], Moscow, 1988, chapter 5.

${ }^{58}$ Bowring, iv. p. 65.

${ }^{59}$ See B. Meehan-Waters, 'Russian Convents and the Secularization of Monastic Property', in Russia and the World of the Eighteenth Century, ed. R.P. Bartlett, A.G. Cross, and K. Rasmussen, Columbus, 1986 pp. 112-15; R.L. Nichols, 'Orthodoxy and Russia's Enlightenment, 1762-1825', in R.L. Nichols and T.G. Stavrou, Russian Orthodoxy under the Old Regime, Minnesota, 1978 (1978).

${ }^{60}$ Baehr, Paradise Myth, p. 14.
} 
which defined the roles they knew best, as a source for the construction of their new identities.

Peter the Great's Drunken Synod exemplifies this process. In a blasphemous parody of the real Synod, the governing body of the Orthodox Church, Peter and his cohorts paraded through the streets of St. Petersburg, parodying orthodox ritual in what were effectively colossal drinking bouts. On one occasion, a 'Prince Priest' had his guests kneel down to be crossed with tobacco pipes in a play on orthodox ministers' ritual of crossing congregations with double branched candelabra. ${ }^{61}$ Thus the nobility did not simply discard traditional forms of religious behaviour or construct completely new, secular forms, borrowed from the West. Rather, the forms of orthodox culture were retained whilst their content was altered, secularised and subverted. This was inevitable when the forms of orthodox ritual- the coronation, procession, etc. -provided the traditional foundations of autocratic power.

Precisely this dynamic is evident in the conception of Catherine's Crimean tour. The tour was planned as the apex of what Catherine and Potemkin referred to as 'the Greek Project,' a plan, formulated in 1780, proposing 'the complete destruction of Turkey and the re-establishment of the ancient Greek empire', that is, the Byzantine Orthodox Empire, with Constantinople at its centre. ${ }^{62}$ Potemkin would be at its head, to be followed by Catherine's grandson, named Constantine in preparation for his destined role. It was this plan that drove Russian aggression in the south and the Crimea. When towns were captured, they were given their ancient Greek names to evoke the return of the Empire: Kherson, after the Byzantine port of Chersonus, Odessa after Odysseus. The Crimea was referred to as Tauris, its ancient name, and Potemkin was entitled 'The Prince of Tauride'. ${ }^{63}$

The tour, then, took the Empress on the 'Road to Byzantium', as an inscription on the triumphal arch through which Catherine passed at Kherson claimed. ${ }^{64}$ If the Empress planned nothing less than the re-establishment of an Orthodox empire, then Potemkin's tour would show her what this Empire might look like. But if we recall

\footnotetext{
${ }^{61}$ See V.O. Kluchevsky, A History of Russia, London, 1926, iv. p. 36-7.

${ }^{62}$ Bezborodko's 'Plan', quoted in Sbornik Russkogo Istoricheskogo Obshchestvo, vol. xxvi p.385. On the Greek Project see H. Ragsdale, 'Evaluating the Tradition of Russian Aggression: Catherine II and the Greek Project', Slavonic and East European Review, cxvi, pp. 91-117.

${ }^{63}$ See Wortman, Scenarios of Power, pp. 138-39 and Baehr, Paradise Myth, p. 48 on Greek imagery in the south.

${ }^{64}$ Wortman, Scenarios of Power, p. 142.
} 
the preparations made for the tour, it will be remembered that Potemkin's new towns and institutions were not those of an ancient Byzantine empire, but those of an idealised, enlightened Russian State. Potemkin built universities and model dairies, not churches. In effect, the Greek Project constituted a fiction, a dramatic theme for the tour in line with Catherine's rhetoric of rebuilding Byzantium and her projects for secularization. As Richard Wortman notes, a 'Byzantine' myth of empire might establish the german princess Catherine's continuity with the House of Romanov, but its actualization could only imply a return to the 'old' order of the pre-Petrine era. ${ }^{65}$

In effect, the tour and the Greek project were another example of the intensified theatricality of Russian culture: the southern territories were a stage, through which Potemkin could demonstrate his Edenic utopia to Catherine, and on which Catherine could play the role of the restorer of an Orthodox Empire. Like the Drunken Synod, the tour rehearsed the forms of Orthodoxy but simultaneously subverted their content, a grand mocking gesture of religious fiction underscored by an enlightened reality. It was within this context that Bentham built his 'secular church'. The Panopticon parodied the Orthodox church for a tour in which such parody constituted the central organizing theme. It presented the Russian nobility with a secular means to control the peasantry, simultaneously an enlightened, productive space, with enough reference to church architecture to make the significance of this gesture clear. The traditional form of the Orthodox church was maintained, but the content transformed. Where the sanctuary became the Lodge, the Russian noble, rather than the clergy, might occupy the privileged space of power. Simultaneously, the Orthodox church provided a model of discipline for Samuel Bentham. He was all too aware of the contrast in behaviour between the English supervisors and his unskilled Russian peasants: replicating the structure which kept the latter group obedient might achieve similar results with the former.

\section{The Panopticon in the theatre of absolutism.}

In Bentham's Prison, Janet Semple suggests that Jeremy Bentham found the inspiration for the Panopticon in a description of Pope Clement XI's St. Michele reformatory, built in Rome in 1703, which Bentham may have seen in Howard's State

\footnotetext{
${ }^{65}$ Ibid., pp. 138-9.
} 
of the Prisons in England and Wales. She fails to note, however, that it was Samuel Bentham, not Jeremy, who devised the structure of the Inspection House. ${ }^{66}$ Semple's mistake is typical of an historiographical approach which takes the Panopticon completely out of context, treating it as the idealized and unrealized invention of Jeremy Bentham. The Panopticon devised by Samuel Bentham was deeply embedded in a specific context. That context was absolutist Russia. No 'simple idea in architecture', the Panopticon made reference to the standard themes and concerns which organised the environment for which it was designed. Besides offering a solution to the immediate problem of 'who will guard the guards', the establishment made reference to the objectives of Potemkin's tour and the dualisms characteristic of Russian culture. The inspector's lodge delimited a space for the nobility to interchange western and foreign, religious and secular, traditional and enlightened roles. In doing so, the Panopticon, like Russia itself, became a theatre of absolutism, not the reified model of a modern society.

Absolutism also provided the material conditions necessary for the development of the Panopticon: it was only with the resources made available by Potemkin that constructing the establishment became a possibility. Writing of his Panopticon to William Pitt in 1787, Bentham maintained: '[i]nventions in the mechanical line [...] are my chief amusement here [in Russia]; and the opportunities, which my situation affords me, of carrying them into practice, form one of the principle ties which attach me to this country ${ }^{67}$ In contrast to the fate of the Panopticon in England, where lack of resources and political ill-will denied Jeremy the opportunity of seeing his penitentiary built, it was only chance that stopped Samuel building his Inspection House, when he was forced to leave Krichev for the war with the Turks: but the land, labour and finance needed for the project were all available in abundance. In fact, when Samuel Bentham returned to Russia in 1806, he succeeded in building a 'Panopticon School of Arts', on the banks of the river Okhta in St. Petersburg. ${ }^{68}$ The project was commissioned by Alexander I, Catherine's grandson and heir to her enlightened beliefs. Soon after its construction, the Tsar was building Panopticons across Russia, as the Okhta School of Arts was "copied in several other private as well

\footnotetext{
${ }^{66}$ Semple, Bentham's Prison, pp. 78-9. Foucault is more careful, but hints that Bentham's inspiration was La Vaux's Menagerie at Versailles. Foucault, Discipline and Punish: The Birth of the Prison, London, 1991, p. 203.

${ }^{67}$ Correspondence $(C W)$, iii. p. 535.

${ }^{68}$ See M. S. Bentham, Life, pp. 295-99.
} 
as Government establishments in that Empire' according to a report given to Jeremy in $1812 .{ }^{69}$ So the Panopticon was by no means emblematic of a new form of power, discontinuous with that of the old regime, as Foucault, Semple or Ignatieff maintain.

But if an examination of the historical context for the creation of the Panopticon reveals it to be immersed in a culture of absolutism, how is it that the Panopticon has come to be seen in an idealized form? Foucault's description is suggestive:

The Panopticon is [...] the diagram of a mechanism of power reduced to its ideal form; its functioning, abstracted from any obstacle [...] must be represented as a pure architectural and optical system; it is in fact a figure of political technology that may and must be detached from any specific use. $^{70}$

Jeremy Bentham's contribution to his brother's project was to make the Panopticon applicable, 'without exception, to all establishments whatsoever, in which [...] a number of persons are meant to be kept under inspection'. ${ }^{71}$ Schools, hospitals, prisons: the list is well known. Universal applicability was, of course, a central theme in Bentham's legal and political philosophy. Throughout his life, Jeremy struggled to create constitutional and criminal codes universally applicable to any country at any time. In a world where human nature and human needs were essentially homogeneous, he argued, 'in comparison of the universally-applying, the extent of the exclusivelyapplying circumstances [is] found very inconsiderable' in law. ${ }^{72}$ He rejected contextspecific rules and customs and attempted to codify them into an abstract, context-free form.

The problem of how to achieve this had perplexed Bentham since the 1780s, when he had written an Essay on the Influence of Time and Place in Matters of Legislation. Here, he defined principles to guide the legislator in the process of decontextualizing laws. It seems he applied these same principles to the Panopticon. To make the establishment universally applicable, Jeremy took the 'plan of a building,

\footnotetext{
${ }^{69}$ Correspondence $(C W)$, viii. p. 224. See also Admiral Chichagov to Samuel Bentham, September 17th 1807. British Library Add. MSS. 33544 fo 316.

${ }^{70}$ Foucault, Discipline and Punish, p. 205.

${ }^{71}$ Bowring, iv. p. 40.
} 
lately contrived by his brother', and transformed it from a specific to an idealized form. In effect, he decontextualized Samuel Bentham's Inspection House. The result, as Foucault notes, was a political technology of a generalized form. But this form was not that of a 'disciplinary' society, but that of the absolutist regime with which Samuel's invention was intimately linked. If Jeremy Bentham proclaimed the Panopticon as a "“Christopher Columbus" egg' in politics, this was not because, as Foucault argues, it represented a new form of power but because it succeeded in decontextualizing an old form. ${ }^{73}$ Jeremy Bentham's achievement was to make 'universally applicable' the 'exclusively applying circumstances' embodied in Samuel's Krichev Panopticon.

Yet Samuel shared in this achievement too. If anything, after his return to England in 1791, Samuel decontextualized the Panopticon even more than his brother. Compare the House of Industry he designed with Samuel Bunce in 1797 with the Krichev design of 1786 . Now the dome and classical references are gone, the structure is made of glass and steel frame, as impressive to the calculating spectators of Hanoverian England as the Krichev church was to Potemkin and the Empress. But if, thanks to the decontextualizing skills of the Bentham brothers, no trace of the Krichev Panopticon's original appearance remained, this new Panopticon still retained the structure of absolute power it had inherited from Russia. Samuel Bentham took full advantage of this fact. In 1806, he submitted a report on his Okhta Panopticon to Admiral Chichagov, head of the Admiralty, to be forwarded to the Emperor Alexander I. Bentham wrote:

Assiduous not to be remarked upon badly, all the supervisors, together with those participating in the membership of the institution, by being turned to the continuous gaze of the main authority, or even the Supreme power himself, [Derzhavnoi samoi vlasti] will be forced to the highest possible perfection regarding its activity. ${ }^{74}$

For a moment he captured the essence of the Panopticon: the ambiguous phrase 'Derzhavnoi samoi vlasti' referring either to the Tsar or to the supreme being with

\footnotetext{
${ }^{72}$ Ibid., p. 561.

${ }^{73}$ Ibid., p. 66; Foucault, Power/Knowledge, p. 148.
} 
UCL Bentham Project Journal of Bentham Studies, vol. 2 (1999)

whom he was synonymous. At Okhta, Samuel Bentham finally succeeded in placing absolute power in the centre of the Inspector's Lodge.

${ }^{74}$ Admiral Chichagov to Alexander I, June 15th 1806. British Library Add. MS. 33544 ff.181-191. 
* Department of History and Philosophy of Science, Cambridge University, Free School Lane, Cambridge CB2 2RH. I would like to thank Simon Schaffer, who supervised this essay, and Jim Secord, Emily James, Luke O’Sullivan, Daniel Alexandrov and Michael Mikeshin for valuable advice and support.

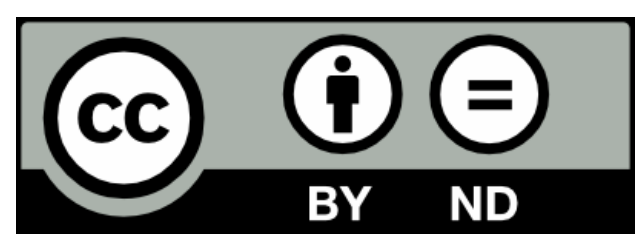

This work is licensed under the Creative Commons Attribution-NoDerivs 3.0 Unported License. The license allows you to copy, distribute, and transmit the work, and make commercial use of it. However, you must attribute the work to the author (but not in any way that suggests that they endorse you or your use of the work), and you cannot alter or transform the work without the author's prior permission. To view a copy of this license, visit http://creativecommons.org/licenses/by-nd/3.0/ or send a letter to Creative Commons, 444 Castro Street, Suite 900, Mountain View, California, 94041, USA. 